\title{
Uji daya hambat ekstrak daun patikan kerbau (euphorbia hirta 1.) terhadap pertumbuhan bakteri staphylococcus aureus dan escherichia coli
}

\author{
${ }^{1}$ Florencia I. Mahmud \\ ${ }^{2}$ Christi Mambo \\ ${ }^{2}$ Henoch Awaloei
}

\author{
${ }^{1}$ Kandidat Skripsi Fakultas Kedokteran Universitas Sam Ratulangi Manado \\ ${ }^{2}$ Bagian Farmakologi dan Terapi Fakultas Kedokteran Universitas Sam Ratulangi Manado \\ Email: florencia.mahmud@yahoo.com
}

\begin{abstract}
Patikan kerbau leaf contains alkaloid, flavonoid, phenol, and tannin can potentially be an antibacterial. The purpose of this research is to test the resisting potency of patikan kerbau leaf extract against Staphylococcus aureus (ATCC25923) dan Escherichia coli (ATCC11229). This was an experimental laboratory study using modified Kirby-Bauer with well diffusion technique at Research and Microbiology Laboratory of MIPA Faculty, Sam Ratulangi University Manado. Patikan kerbau leaf extract was obtained by using $96 \%$ etanol maceration. Extract concentrations used in this study were $50 \mathrm{mg} / \mathrm{ml}, 25 \mathrm{mg} / \mathrm{ml}, 12.5 \mathrm{mg} / \mathrm{ml}$ and $6.25 \mathrm{mg} / \mathrm{ml}$. Ciprofloxacin was used as the positive control and CMC as the negative control. The CMC showed no inhibition zone. Ciprofloxacin had the widest zone of inhibition. The average of inhibition zone diameters produced by ciprofloxacin was $33,3 \mathrm{~mm}$ on S. aureus and $33 \mathrm{~mm}$ on E.coli. Euphorbia hirta leaf extract concentration of $50 \mathrm{mg} / \mathrm{ml}$ resulted in average inhibition zone diameter of $18.83 \mathrm{~mm}$ on S.aureus and $17.83 \mathrm{~mm}$ on E.coli. Extract concentration of $25 \mathrm{mg} / \mathrm{ml}$ resulted in $17.33 \mathrm{~mm}$ on $S$. aureus and $16.83 \mathrm{~mm}$ on E.coli. Extract concentration of $12,5 \mathrm{mg} / \mathrm{ml}$ resulted in $15.5 \mathrm{~mm}$ on $S$. aureus and $14.83 \mathrm{~mm}$ on E.coli. Then, extract concentration of $6.25 \mathrm{mg} / \mathrm{ml}$ resulted in $15.16 \mathrm{~mm}$ on S. aureus and $13.3 \mathrm{~mm}$ on E.coli. Conclusion: Extract of Euphorbia hirta leaf has potential inhibitory effect towards bacterial growth of $S$. aureus and E. coli. Moreover, the inhibitory effect of Euphorbia hirta extract is greater towards S. aureus rather than E.coli
\end{abstract}

Keywords: antibacterial, patikan kerbau leaf extract, S. aureus, E. coli

\begin{abstract}
Abstrak: Daun patikan kerbau mengandung alkaloid, flavonoid, fenol dan tanin yang berpotensi sebagai antibakteri. Penelitian ini bertujuan untuk mengetahui uji daya hambat ekstrak daun patikan kerbau terhadap Staphylococcus aureus (ATCC25923) dan Escherichia coli (ATCC11229). Jenis penelitian ini ialah eksperimental laboratorium di Laboratorium Penelitian dan Mikrobiologi Fakultas MIPA Universitas Sam Ratulangi Manado dengan metode KirbyBauer yang dimodifikasi dengan sumuran. Ekstrak daun patikan kerbau diperoleh dari proses maserasi dengan etanol $96 \%$. Konsentrasi ekstrak yang digunakan dalam penelitian ialah $50 \mathrm{mg} / \mathrm{ml}, 25 \mathrm{mg} / \mathrm{ml}, 12,5 \mathrm{mg} / \mathrm{ml}$ dan $6,25 \mathrm{mg} / \mathrm{ml}$. Siprofloksasin digunakan sebagai kontrol positif dan CMC sebagai kontrol negatif. Pada penelitian ini CMC yang tidak mempunyai zona hambat. Siprofloksasin memiliki diameter zona hambat yang paling besar. Rerata diameter zona hambat yang dihasilkan oleh siprofloksasin adalah $33,3 \mathrm{~mm}$ terhadap bakteri S.aureus dan $33 \mathrm{~mm}$ pada bakteri E.coli. Ekstrak daun patikan kerbau konsentrasi $50 \mathrm{mg} / \mathrm{ml}$ menghasilkan diameter zona hambat rata-rata sebesar $18,83 \mathrm{~mm}$ pada bakteri S.aureus dan $17,83 \mathrm{~mm}$ pada bakteri E.coli. Ekstrak daun patikan kerbau konsentrasi $25 \mathrm{mg} / \mathrm{ml}$ sebesar $17,3 \mathrm{~mm}$ pada bakteri S.aureus dan $16,83 \mathrm{~mm}$ pada bakteri E.coli. Ekstrak daun patikan kerbau konsentrasi 12,5mg/ml sebesar 15,5 mm pada bakteri S.aureus dan $14,83 \mathrm{~mm}$ pada bakteri E.coli. Kemudian, konsentrasi 6,25mg/ml sebesar 15,16 pada bakteri S.aureus dan 13,3 mm pada bakteri E.coli. Simpulan: Ekstrak daun patikan kerbau berpotensi memiliki efek daya hambat terhadap pertumbuhan bakteri S.aureus dan E.coli. Daya hambat ekstrak daun patikan kerbau lebih besar pada S.aureus daripada E.coli Kata kunci: antibakteri, ekstrak daun srikaya, S. aureus, E. coli
\end{abstract}


Daun patikan kerbau (Euphorbia hirta L.) dikenal oleh masyarakat Angola untuk mengobati penyakit diare dan disentri. ${ }^{1}$ Daun ini mengandung alkaloid, sterol, fenol, triterpenoid, flavonoid, tanin, kolin dan pada bunganya terkandung asam elagik. ${ }^{2}$ Senyawa alkaloid, flavonoid, dan fenolik berpotensi sebagai antibakteri. ${ }^{3,4}$

Escherichia coli dan Staphylococcus aureus merupakan salah satu penyebab diare pada anak di negara berkembang.

Berdasarkan informasi diatas, penulis ingin mengetahui apakah daun patikan kerbau (Euphorbia hirta L.) mempunyai efek antibakteri terhadap Staphylococcus aureus dan Escherichia coli.

\section{METODE PENELITIAN}

Jenis penelitian ini ialah eksperimental laboratorium dan dilakukan di Laboratorium Penelitian dan Mikrobiologi Program studi Farmasi FMIPA Universitas Sam Ratulangi. Tahap-tahap penelitian ialah sterilisasi alat, pengambilan sampel, pembuatan ekstrak daun patikan kerbau dengan cara maserasi, pengenceran ekstrak daun patikan kerbau, pembuatan media peremajaan Nutrient Agar (NA), MullerHinton Agar (MHA), suspensi bakteri dan pengujian bakteri. Siprofloksasin sebagai kontrol positif sedangkan Carboxy Methyl Celullose (CMC) sebagai kontrol negatif. Ekstrak daun patikan kerbau dengan berbagai konsentrasi $(50 \mathrm{mg} / \mathrm{ml}, 25 \mathrm{mg} / \mathrm{ml}$, $12,5 \mathrm{mg} / \mathrm{ml}$ dan $6,25 \mathrm{mg} / \mathrm{ml}$ ), kontrol positif dan kontrol negatif diteteskan sebanyak $50 \mu 1$ pada sumur yang berbeda, kemudian cawan Petri dimasukkan dalam inkubator pada suhu $37^{\circ} \mathrm{C}$ selama $18-24$ jam. Diamati dan diukur diameter zona hambat yang terbentuk dengan menggunakan mistar satuan milimeter, pada 2 kali pengamatan yakni 18 jam inkubasi dan 24 jam inkubasi.

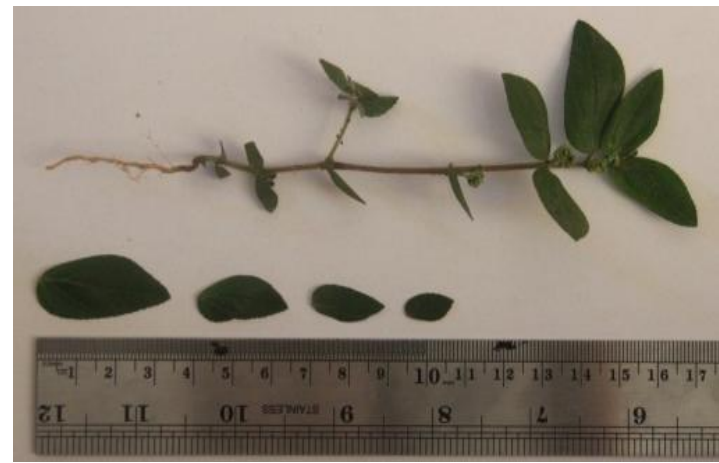

Gambar 1. Daun Euphorbia hirta L

Zona bening merupakan petunjuk kepekaan bakteri terhadap bahan antibakteri yang digunakan sebagai bahan uji dan dinyatakan dengan diameter zona hambat. Diameter zona hambat dapat dihitung dengan rumus:

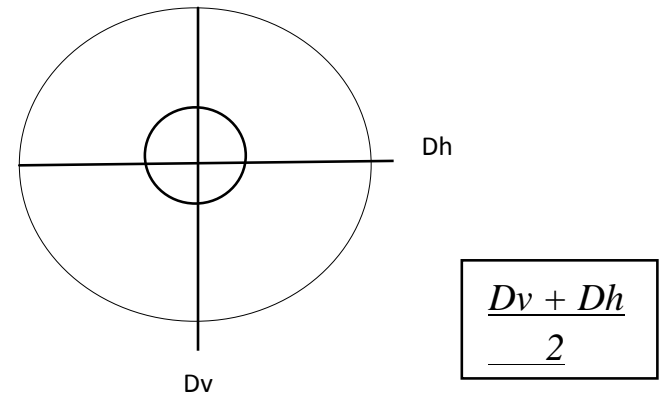

Dh : Diameter horizontal

Dv : Diameter vertikal

\section{HASIL PENELITIAN}

Hasil pengujian daya hambat ekstrak daun patikan kerbau terhadap pertumbuhan Staphylococcus aureus dan Escherichia coli pada pengamatan 18 jam dan 24 jam inkubasi dengan 3 kali pengulangan menunjukan hasil yang positif. Hal ini ditunjukkan dengan terbentuknya zona jernih disekitar sumuran kontrol positif dan ekstrak daun patikan kerbau. Sekitar sumuran kontrol negatif tidak terbentuk zona jernih. 
A. Pengamatan 1

Pengamatan 1 dilakukan pada waktu inkubasi 18 jam, yaitu pukul 12.10 WITA.

Tabel 1. Diameter zona hambat kontrol dan perlakuan pada S.aureus pada pengamatan 1

\begin{tabular}{lllllll}
\hline Cawan & \multicolumn{5}{c}{ Staphylococcus aures } \\
Petri & $50 \mathrm{mg} / \mathrm{ml}$ & $25 \mathrm{mg} / \mathrm{ml}$ & $12,5 \mathrm{mg} / \mathrm{ml}$ & $6,25 \mathrm{mg}, \mathrm{ml}$ & $\mathrm{K}+$ & $\mathrm{K}-$ \\
\hline SA I & 18 & 17 & 17 & 15,5 & 37,5 & 0 \\
SA II & 19,5 & 18 & 16 & 15 & 40 & 0 \\
SA III & 18,5 & 16,5 & 13,5 & 13,5 & 39 & 0 \\
Rata-rata & 18,67 & 17,16 & 14,67 & 14,67 & 38,83 & 0 \\
\hline
\end{tabular}

Tabel 2. Diameter zona hambat kontrol dan perlakuan pada E.coli pada pengamatan 1

\begin{tabular}{lllllll}
\hline $\begin{array}{l}\text { Cawan } \\
\text { Petri }\end{array}$ & $50 \mathrm{mg} / \mathrm{ml}$ & $25 \mathrm{mg} / \mathrm{ml}$ & $12,5 \mathrm{mg} / \mathrm{ml}$ & $6,25 \mathrm{mg}, \mathrm{ml}$ & $\mathrm{K}+$ & $\mathrm{K}-$ \\
\hline EC I & 17 & 18 & 14,5 & 10 & 32,5 & 0 \\
EC II & 17,5 & 17 & 13 & 13 & 31,5 & 0 \\
EC III & 18 & 14,5 & 13 & 11 & 34,5 & 0 \\
Rata-rata & 17,5 & 16,5 & 13,3 & 11,3 & 32,83 & 0 \\
\hline
\end{tabular}

Keterangan : $50 \mathrm{mg} / \mathrm{ml}$. konsentrasi $50 \mathrm{mg} / \mathrm{ml} ; 25 \mathrm{mg} / \mathrm{ml}$. konsentrasi $25 \mathrm{mg} / \mathrm{ml} ; 12,5 \mathrm{mg} / \mathrm{ml}$.

konsentrasi 12,5mg/ml; $6,25 \mathrm{mg} / \mathrm{ml}$. konsentrasi $6,25 \mathrm{mg} / \mathrm{ml}$; K-. kontrol negatif; $\mathrm{K}+$. kontrol positif.

B. Pengamatan 2

Pengamatan 2 dilakukan pada waktu inkubasi 24 jam, yaitu pukul 18.10 WITA.

Tabel 3. Diameter zona hambat kontrol dan perlakuan pada S.aureus pada pengamatan 2

\begin{tabular}{|c|c|c|c|c|c|c|}
\hline \multirow{2}{*}{$\begin{array}{l}\text { Cawan } \\
\text { Petri }\end{array}$} & \multicolumn{6}{|c|}{ Staphylococcus aures } \\
\hline & $50 \mathrm{mg} / \mathrm{ml}$ & $25 \mathrm{mg} / \mathrm{ml}$ & $12,5 \mathrm{mg} / \mathrm{ml}$ & $6,25 \mathrm{mg}, \mathrm{ml}$ & $\mathrm{K}+$ & $\mathrm{K}-$ \\
\hline SA I & 18 & 18 & 16,5 & 15 & 35,5 & 0 \\
\hline SA II & 20 & 17,5 & 16,5 & 16 & 27,5 & 0 \\
\hline SA III & 18,5 & 16,5 & 13,5 & 14,5 & 37 & 0 \\
\hline Rata-rata & 18,83 & 17,3 & 15,5 & 15,16 & 33,3 & 0 \\
\hline
\end{tabular}

Tabel 4. Diameter zona hambat kontrol dan perlakuan pada E.coli pada pengamatan 2

\begin{tabular}{lllllll}
\hline $\begin{array}{l}\text { Cawan } \\
\text { Petri }\end{array}$ & $50 \mathrm{mg} / \mathrm{ml}$ & $25 \mathrm{mg} / \mathrm{ml}$ & $12,5 \mathrm{mg} / \mathrm{ml}$ & $6,25 \mathrm{mg}, \mathrm{ml}$ & $\mathrm{K}+$ & $\mathrm{K}$ - \\
\hline EC I & 17 & 17 & 15,5 & 13 & 33 & 0 \\
EC II & 17,5 & 17 & 15 & 14 & 31 & 0 \\
EC III & 19 & 16,5 & 14 & 13 & 35 & 0 \\
Rata-rata & 17,83 & 16,83 & 14,83 & 13,3 & 33 & 0 \\
\hline
\end{tabular}

Keterangan : $50 \mathrm{mg} / \mathrm{ml}$. konsentrasi $50 \mathrm{mg} / \mathrm{ml} ; 25 \mathrm{mg} / \mathrm{ml}$. konsentrasi $25 \mathrm{mg} / \mathrm{ml} ; 12,5 \mathrm{mg} / \mathrm{ml}$.

konsentrasi $12,5 \mathrm{mg} / \mathrm{ml} ; 6,25 \mathrm{mg} / \mathrm{ml}$. konsentrasi $6,25 \mathrm{mg} / \mathrm{ml}$; K-. kontrol negatif; $\mathrm{K}+$. kontrol positif

\section{BAHASAN}

Uji daya hambat dilakukan dengan menggunakan metode difusi dengan sumuran. Hal ini dipilih, karena metode ini mudah untuk dilakukan, murah dan tidak membutuhkan waktu yang banyak. Menurut penelitian oleh Valgas C dkk, metode difusi dengan sumuran memiliki tingkat sensibilitas lebih tinggi dibanding dengan varian cakram. ${ }^{5}$

Pengamatan dilakukan pada 2 waktu berbeda yaitu 18 jam dan 24 jam setelah inkubasi, untuk melakukan perbandingan ukuran dan kejernihan zona hambat. Zona hambat yang terbentuk setelah 18 jam masa inkubasi, terlihat jelas namun lebih kecil 
dibandingkan pengamatan setelah 24 jam inkubasi (gambar 7).

Berdasarkan hasil pengamatan yang dilakukan pada kelompok perlakuan, terjadi peningkatan rata-rata diameter zona hambat seiring dengan meningkatnya konsentrasi ekstrak daun patikan kerbau $(50 \mathrm{mg} / \mathrm{ml}>$ $25 \mathrm{mg} / \mathrm{ml}>12,5 \mathrm{mg} / \mathrm{ml}>6,25 \mathrm{mg} / \mathrm{ml}$ ). Hasil ini serupa dengan penelitian sebelumnya oleh Hamdiyati Y dkk terhadap bakteri Staphylococcus epidermidis yang menunjukan bahwa semakin besar konsentrasi ekstrak, semakin besar diameter zona hambat yang terbentuk. $^{6}$ Adanya zona hambat, dipengaruhi oleh kandungan senyawa aktif yang terdapat pada ekstrak daun patikan kerbau diantaranya ialah flavonoid. Flavonoid telah teruji memiliki efek antibakteri. Mekanisme kerja dari senyawa ini ialah membentuk kompleks dengan protein mikroba sehingga enzim yang berguna untuk proses replikasi mikroba menjadi nonaktif. Selain itu, flavonoid juga dapat merusak membran sel mikroba.

Pada pengamatan, zona hambat yang terbentuk disekitar sumur yang diberi perlakuan dengan ekstrak daun patikan kerbau berwarna kecoklatan. Diduga hal tersebut dipengaruhi oleh kandungan tanin dalam ekstrak. ${ }^{9}$ Nama tanin di diambil dari bahasa Prancis tanin yang artinya penyamak. Tanin merupakan senyawa aktif yang dapat ditemukan pada sebagian besar tanaman dan terdapat zat pada tanin yang mempunyai sifat antibakteri. ${ }^{10}$ Selain itu, hasil pengukuran menunjukan diameter rata-rata zona hambat yang terbentuk pada media tanam bakteri S.aureus lebih besar dari pada bakteri E.coli. Hal ini didukung oleh penelitian-penelitian sebelumnya yang menunjukan bakteri Gram positif lebih rentan terhadap zat aktif dalam ekstrak dibandingkan bakteri Gram negatif, karena bakteri Gram positif mempunyai membran luar berupa lapisan peptidoglikan yang mudah menyerap ekstrak. Sebaliknya, bakteri Gram negatif mempunyai membran luar yang terdiri dari lipopolisakarida yang dapat menghalangi penetrasi ekstrak ke dalam sel mikroba. ${ }^{11,12}$
Zona hambat yang terbentuk pada kontrol positif (siprofloksasin) terlihat bening dan lebih besar dibanding kelompok perlakuan pada tiap pengamatan yang dilakukan (tabel 9). Zona hambat tersebut kemudian mengecil setelah dibiarkan 48 jam inkubasi karena terjadi pertumbuhan bakteri di sekitar zona hambat yang terbentuk sebelumnya. Siprofloksasin dipilih sebagai kontrol positif karena merupakan antibiotik spektrum luas yang merupakan salah satu obat pilihan untuk infeksi bakteri E.coli dan sensitif terhadap bakteri S.aureus yang resisten terhadap metisilin. $^{13-15}$

Pada penelitian ini, tidak ditemukan adanya zona hambat pada kontrol negatif. Kontrol negatif yang digunakan ialah larutan CMC, yang merupakan larutan pengencer kontrol positif dan ekstrak daun patikan kerbau. Hal ini membuktikan bahwa larutan pengencer tidak berpengaruh sebagai antimikroba. Larutan CMC dipilih sebagai kontrol negatif karena selain dipakai untuk mengencerkan ekstrak daun patikan kerbau yang padat, larutan ini juga merupakan emulgator yang bisa mengemulsi minyak yang terkandung dalam ekstrak.

Dari hasil penelitian ini disimpulkan bahwa ekstrak daun patikan kerbau memiliki efek antibakteri untuk menghambat pertumbuhan bakteri S.aureus dan E.coli, tetapi zona hambatnya lebih kecil dibandingkan dengan antibiotik siprofloksasin.

\section{SIMPULAN}

Ekstrak daun patikan kerbau memiliki efek daya hambat terhadap pertumbuhan bakteri S.aureus dan E.coli. Daya hambat ekstrak daun patikan kerbau lebih besar pada S.aureus daripada E.coli.

\section{DAFTAR PUSTAKA}

1. Singh G, Kumar P. Phytochemical study and screening for antimicrobial activity of flavonoid Euphorbia hirta. 2013 Sept 9. [cited 2016 Des 5]. Available from: https://www.ncbi.nlm.nih.gov/pmc/ar 
ticles/PMC3783663/?report=reader\#! $\mathrm{po}=3.57143$

2. Assidqi K, Tjahjaningsih W, Sigit $\mathrm{S}$. Potensi ekstrak daun patikan kebo (Euphorbia hirta) sebagai antibakteri terhadap Aeromonas hydrophila secara in vitro. Journal of marine and coastal science. 2012;2:133-24.

3. Kabera JN, Semana E, Mussa AR, He X. Plant secondary metabolites: Biosyntesis, classification, function and pharmacological properties. Journal of pharmacy and pharmacology. 2014;2:377-92.

4. Chitra M, Muga V, Dhanarasu S, Alhazimi AM. Screening of phytochemical and in vitro activity of Euphorbia hirta L. Journal of chemical and pharmaceutical research. 2011;3(6):110-114.

5. Valgas C, de Souza SM, Smania EF, Smania A Jr. Screening methods to determine antimicrobial activity of natural product. Brazilian journal of microbiology. 2007;38:369-80.

6. Hamdiyati Y, Kusnadi, Rahadian I. Aktivitas antibakteri ekstrak daun patikan kebo (Euphorbia hirta) terhadap pertumbuhan bakteri Staphylococcus epidermidis. Jurnal pengajar MIPA.2008;12

7. Saifudin A. Senyawa alam metabolit sekunder: teori, konsep dan teknik pemurnian. Edisi ke-1. Yogyakarta: Deepublish publisher; 2014. h.1-35.

8. Kumar S, Pandey AK. Chemistry and biological activities of flavonoids: an overview. Hindawi. 2013;2013:1-9.

9. Nafisah M, Tukiran, Suyatno, Hidayati N. Uji skrining fitokimia pada ekstrak heksan, kloroform dan metanol dari tanaman patikan kebo (Euphorbia hirta). Prosiding seminar nasional kimia; 2014 Sept 20; Surabaya. Surabaya: Jurusan kimia FMIPA Universitas Negeri Surabaya; c2014.

10.Praveen KA. Kumud U. Tannins are astrigent. Journal of pharmacognosy and phytochemistry. 2012;3:45.

11.Biswas $\mathrm{B}$, Rogers $\mathrm{K}$, McLaughlin $\mathrm{F}$, Daniels D, Yadav A. Antimicrobial activities of leaf extract of guava (Psidium guajava L.) on two gramnegative and gram positive bacteria. International journal of microbiology. 2013;2013:1-5.

12.Behbahani BA, Yazdi FT, Mortzavi A, Gholiand MM, Zendeboodi F, Vasiee A. Antimicrobial effect of Carboxy Mehtyl Cellulose (CMC) containing aqueous and ethanolic Eucalyptus camaldulensis L. Leaves extract against Streptococcus pyogenes, Pseudomonas aeruginosa and Staphylococcus epidermidis. Journal of paramedical sciences. 2014;5:59-68.

13.Petri WA. Senyawa antimikroba lanjutan sulfonamida, trimetoprimsulfametoksazol, kuinolon, dan obat untuk infeksi saluran urin. In: Hardman JG, Limbird LE, editors. Goodman \& Gilman dasar farmakologi terapi. Ed 10. Jakarta: EGC, 2012. p.1154-59

14.Setiabudy R. Antimikroba lain. In: Ganiswarna SG, Setiabudy R, Suyatna FD, Purwantyastuti, Nafrialdi, editors. Farmakologi dan terapi. Edisi 4. Jakarta: Gaya Baru; 2002.p.682-5.

15.Food and drug administrator organization. Cipro. USA: Departement of health and human service; 2004. 